\title{
ENIGMAS PARA RESOLVER: LOS ÚLTIMOS DÍAS DE FranÇOIS DUCASSE
}

\author{
ENIGMAS TO SOLVE: THE LAST DAYS \\ OF FRANÇOIS DUCASSE
}

\author{
Pablo Rocca \\ Universidad de la República \\ Montevideo, Uruguay \\ ORCID 0000-0002-0925-4643
}

\begin{abstract}
Resumen
A fines de la década del noventa, la investigación de Jean-Jacques Lefrère sobre Isidore Ducasse, su familia, sus presuntos amigos y su tiempo permitió acercarse a algunas figuras que, hasta entonces $-\mathrm{y}$ a pesar del esfuerzo pionero de los Guillot Muñoz y de Pichon-Riviére-, eran oscuras siluetas o contornos imprecisos. Este trabajo propondrá algunas hipótesis sobre cómo pudieron ser los últimos días del anciano y retirado diplomático François Ducasse, quien sobrevivió a su hijo casi veinte años, y cómo pudo ser el reducido ambiente en que se movía. Para eso ha sido fundamental una documentación aún inexplorada -hasta donde sabemos-, que se anexa parcialmente al final del artículo. Tras sus pasos perdidos en su larga residencia final en el Hotel des Pyramides, donde murió el 18 de noviembre de 1889, se atisba el espectro de Lautréamont.
\end{abstract}

Palabras clave: François e Isidore Ducasse; Montevideo; Fin de siglo.

\section{Resumo}

No final dos anos 1990, a pesquisa de Jean-Jacques Lefrère sobre Isidore Ducasse, sua família, seus supostos amigos e seu tempo permitiram uma renovada aproximação de algumas figuras que, até entáo - apesar dos esforços dos irmáos Guillot Muñoz e de Pichon-Riviére -, eram silhuetas escuras, contornos imprecisos. Este trabalho anotará algumas hipóteses sobre como poderiam ter sido os últimos dias de François Ducasse, o idoso diplomata aposentado que sobreviveu a seu filho quase 20 anos,

\section{Abstract}

At the end of the nineties, Jean-Jacques Lefrère's research on Isidore Ducasse, his family, his alleged friends and his time allowed him to get close to some figures with imprecise contours. This investigation reinforced the works of Gervasio and Álvaro Guillot Muñoz and of the Pichon-Riviére, mainly. Now, this text will propose some hypotheses about the last days of François Ducasse, the retired old diplomat who survived his son Isidore almost twenty years, and how could it be the litle medium 
e como poderia ter sido o pequeno círculo no qual ele se movimentava. Para a elaboração deste trabalho foi fundamental uma documentação ainda inexplorada - tanto quanto sabemos -, que parcialmente se anexa ao fim do artigo. Após esses passos perdidos na sua longa residência final no Hotel des Pyramides, de Montevidéu, onde morreu em 18 de novembro de 1889 , ainda fica o espectro de Lautréamont.

Palavras-chave: François e Isidore Ducasse; Montevidéu; Fim do século. in wich he moved. For the preparation of the work it has been fundamental a documentation still unexplored -as far as we know-, partially annexeted to the end of the article. The spectrum of Lautréamont can be stay after the lost steps of François Ducasse in his long final residence in the Hotel des Pyramides, in Montevideo, where he died on November 18, 1889.

Keywords: François and Isidore Ducasse; Montevideo; End of Century.

Por azar, en el verano de 2016, en uno de los índices de los despachos judiciales que custodia el Archivo General de la Nación, tropecé con algo asombroso. Por medio de ese libraco de tapas negras, páginas manuscritas y maltrechas supe que, con poca diferencia de tiempo, murieron en Montevideo dos personas de nombre Francisco Ducasse. La curiosa redundancia me movió a solicitar los expedientes respectivos. Una vez con ellos, el primer conjunto de documentos, más bien pocos, en rigor remitía indirectamente a cierto Francisco Ducasse que había perdido la vida atropellado por una locomotora del Ferrocarril Central del Uruguay en fecha que el escrito no determina. Se trataba, más que nada, de una demanda. El 5 de noviembre de 1886 su viuda, la Sra. María Arens de Ducasse, quien no sabía firmar y se encontraba "en estado de pobreza por la forma exigida por la ley", se presentó ante el juez a fin de nombrar un procurador para que llevara adelante un reclamo de indemnización (ARCHIVO GENERAL DE LA NACIÓN -AGN/AJ-, 1886). ${ }^{1}$

1 Jean-Jacques Lefrère hace notar que la Guía General Comercial de La Tribuna, editada en 1877 "mentionne un Francisco Ducasse, qui demeurait au 125 de la calle Paysandú" (LEFRÈRE, 1998, p. 306, n. 57). Tal vez sea el mismo o, más curiosamente aun, quizá se trate de un tercer François Ducasse. La dirección de María Arens de Ducasse no aparece entre los papeles consultados, aunque se indica que residían en la localidad de Santa Lucía, Departamento de Canelones. Se hace constar que toda transcripción respeta, aquí, las particularidades ortográficas y sintáticas de los originales. Sólo en los casos en que podría dar lugar a confusiones se hace notar tal posibilidad. 


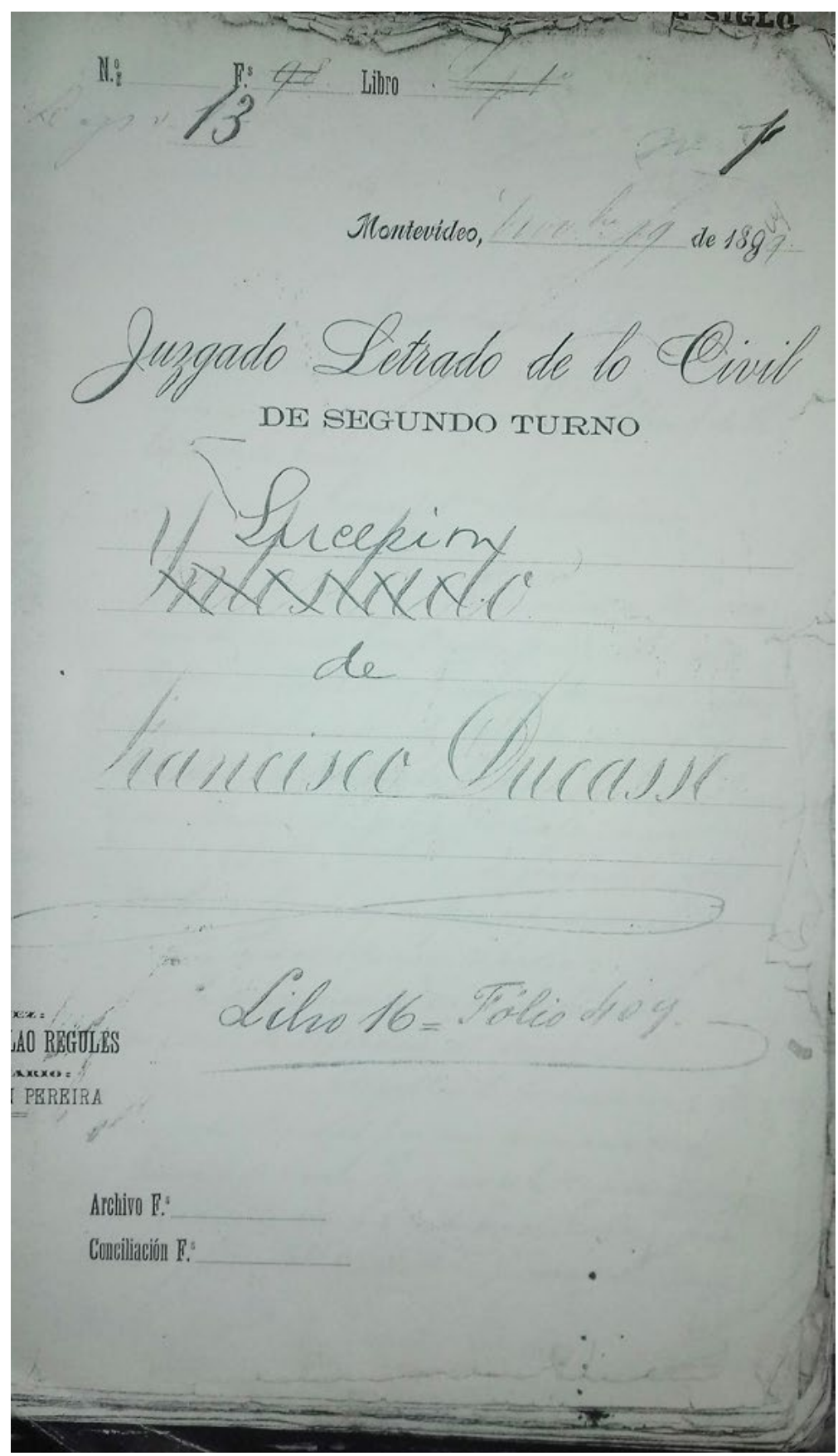

Figura 1: Carátula Sucesión de Francisco Ducasse. 
El segundo legajo contiene 412 fojas y está caratulado "Sucesión de Francisco Ducasse” (Figura 1), aunque la primera palabra se agregó luego de tachar "Intestado". Este era el verdadero hallazgo con otras proyecciones mayores a la historia de la vida corriente. A través de su padre este conjunto de papeles podía llevara una imagen más completa de Isidore Lucien Ducasse, su hijo ausente y prematuramente muerto lejos, en Paris, el 24 de noviembre de 1870, casi veinte ańos antes de que se iniciara este expediente a causa del deceso de François Ducasse ocurrido el 18 del mismo mes, pero de 1889.

En efecto, el grueso expediente se inició el mismo día fatal con una notificación del agente actuante a su Jefe Político y de Policía de la Capital. En la nota, se da cuenta de la muerte de "Francisco Ducasse, de ochenta años de edad, viudo", a causa de una "afección al corazón", según certificado que firmó el doctor Romeu, "como a las 4 p. m. [...] en la pieza No 9 del Hotel Piramides sito en la calle Sarandí No 183" (AGN/AJ, 1889, folio 1). ${ }^{2}$ La última actuación del proceso está fechada un año y medio después, el 29 de mayo de 1891, y corresponde a una breve comunicación del alguacil a cargo de los objetos del fallecido, que ya habían sido rematados (ver detalle en Anexo II). En las 410 fojas intermedias, hay un largo ir y venir procesal, en el que algunos documentos, como en el movimiento de las olas, nos alejan mientras nos acercan al enigma de François Ducasse y el de su hijo.

Si toda vida parece un acarreo continuo de insatisfacciones a las respuestas taxativas, la de Isidore Ducasse y las de sus padres son más esquivas de lo acostumbrado. Su breve vida en claroscuro -y su tan citada versificada sentencia "je ne laisserai pas de Memoires"estimularon una necesidad casi compulsiva de crear biografías. Con el auxilio de estos papeles que, hasta donde sé, no han sido explorados o utilizados en investigación alguna, con otros signos y, por supuesto, con los aportes fundamentales que me preceden estas notas discurrirán sobre una imagen en la dinámica de una historia colectiva ya espectral que, por eso mismo, se desdibuja.

2 El oficial equivoca la puerta de entrada del establecimiento, que era por la calle Ituzaingó, a la que correspondía esa numeración y no por la calle de Sarandí, el eje de la ciudad vieja, a pesar de que por esta había otra puerta de acceso desde el tiempo en que el Hotel des Pyramides era, como se verá, café y restaurante. 
Poco quedaba del Montevideo al que llegó con treinta años de edad François Ducasse. Su desembarco se produjo a fines de 1839, cuando la ciudad estaba próxima a sufrir el conflicto bélico más largo y más cruel vivido en cualquier tiempo local. ${ }^{3}$ Apenas rozaba los treinta mil habitantes ese conglomerado urbano que se dispersaba en magro caserío no bien traspuesta la puerta de la Ciudadela. Entre los extranjeros, que en febrero de 1843 , cuando comenzó la prolongada guerra que agotaría el territorio de la República Oriental, eran algo menos de veinte mil, los franceses sumaban más de cinco millares. Constituían un tercio del total los inmigrantes en Montevideo, casi un quince por ciento del total de la población de toda la desolada geografía del país (apud ARREDONDO, 1942). ${ }^{4}$ Como ya se ha observado, en su mayoría esos inmigrantes eran de zonas rurales, en especial de Bigorre y de Bearn (DUPREY, 1952, p. 160-162). Los dialectos que se hablaban en la ciudad superaban al francés parisino, lo cual también se ha notado al calibrar los efectos de estas variaciones de tal lengua en la propia escritura de Lautréamont (RODRÍGUEZ MONEGAL; PERRONE, 1995, p. 74-78). De esa época son unos versos de autor anónimo, aparecidos en una gacetilla porteńa, que recoge Andrés Lamas en su libro Notice sur la Republique Oriental de l'Uruguay, publicado en París en 1851:

\author{
Quien quiera hablar en francés \\ En Catalán, en Vascongado \\ Todo idioma arrevesado \\ Y que no sepa quién es
}

3 François Ducasse era hijo de Louis Ducasse y de Marthe d'Amaré. Nació el 12 de marzo de 1809 en la commune de Bazet, Canton de Tarbes-Nord. El matrimonio tuvo ocho hijos. Hasta el 4 de septiembre de 1839 François trabajó en el Conseil municipal, fecha en la que renunció a su cargo. Pronto partió para Montevideo. Sus hermanos, Jean (28 años) y Bernard-Lucien (24 años) siguieron para Córdoba, Argentina. Cuando François comenzó a trabajar en el Consulado de Francia en Montevideo, "en qualité de commis", ejercía como canciller Arséne Isabelle (LEFRÈRE, 1998, p. 11; 24; 34), figura clave de la colectividad francesa durante el siglo XIX. A su muerte, la legación francesa se hizo cargo de sus exequias y entierro. Dispenso otras informaciones ya difundidas, que pueden consultarse en la bibliografía de este mismo trabajo.

4 Estos cálculos están, también, en el anónimo Almanaque de la República Oriental del Uruguay para el año 1844, Montevideo, Imprenta del Nacional, 1844, p. 19. 
Y hallarse en un entremés

$\mathrm{O}$ en un extraño museo

Vaya hoy a Montevideo

Nótese que los ocurrentes aunque deslucidos versos de esta séptima no mentan a los italianos ni los dialectos de España (LAMAS, 1851). Una comprobación empírica, que viene directo al caso, ayuda a definir mejor los contornos de la situación: a pocos días del 4 de abril de 1846, fecha del nacimiento del hijo de François Ducasse y Céleste Davezac, el Comercio del Plata, principal diario de la ciudad sitiada, informó que entre el 13 y el 19 de abril habían nacido 29 niños. Trece eran de madres naturales de esta tierra sudamericana; dieciséis eran hijos de madres inmigrantes, seis de ellas francesas; entre los padres, sólo cinco habían nacido en la República Oriental, seis venían de Francia, el mismo número de mujeres de ese origen, con las que previsiblemente habían formado pareja, allá o aquí. ${ }^{5}$

La presencia y la demanda de primeras letras para connacionales y criollos (o los nativos de otras lenguas que habitaban en Montevideo) era cosa corriente aun en la ciudad sitiada, adonde pese al conflicto que tenía un poderoso ejército a sus puertas no dejaban de afluir migrantes franceses, entre otros. A falta de una ocupación posible en medio de esa aguda crisis las mujeres se ofrecían, más que los hombres, como preceptoras y profesoras de lengua. Su aporte en la formación de la élite y los sectores medios criollos en la lengua francesa e inglesa y hasta italiana (la primera y la última, además, sonaban por todos los rincones de la pequeña ciudad) fue decisivo y tuvo un largo alcance en la cultura del país (ROCCA, 2016). En el mismo Comercio del Plata tres meses antes del nacimiento de Isidore un aviso, entre muchos, ejemplifica esta circunstancia habitual:

Una señora francesa. Recien llegada de París, se compromete á dar lecciones de francés en casas particulares, á aquellas Señoritas que quieran favorecerla con su con-

5 "Hijos de padre oriental 5, de español 2, de argentino 4, de francés 6, de italiano 6, de africano 2 , de nacionalidad ignorada 4. Hijos de madre oriental, 13, de española 1, de argentina 4 , de francesa 6 , de italiana 3 , de africana 1 - de nacionalidad ignorada 1. [...]" (Sin firma, Resumen del movimiento ocurrido en las dos parroquias de la Capital, del 13 al 19 de abril [de 1846], Comercio del Plata, Montevideo, n. 161, 23/IV/1846, p. 4, col. 1). 
fianza. Vive en la calle de Misiones, número 65, donde podrán verla las personas que la necesiten (Sin Firma, Comercio del Plata, n. 86, 14/I/1846, p. 4., col. 1).

A grandes rasgos ese era el cuadro humano en que la presencia francesa desbordaba por las estrechas calles de la atribulada ciudad. Medio siglo más tarde la población de Montevideo se había multiplicado por nueve. Ultrapasaba el cuarto de millón de habitantes y seguía nutriéndose del aporte inmigratorio. Cálculos serios, anteriores al primer censo oficial, aseguran que la mitad de quienes vivían en la capital uruguaya a fines de la década del ochenta habían nacido fuera de fronteras nacionales (ODDONE, 1966). Ahora predominaban los italianos y españoles. En sus últimos días, aunque la lengua francesa y su universo cultural continuara con altos prestigios, al viejo funcionario de la legación francesa no le iba a ser tan fácil cruzarse con jóvenes paisanos, así no tuvieran la supuesta amplia cultura literaria y filosófica que él poseía sobre la que, hasta ahora, no hay pruebas fehacientes. Estas dificultades últimas de encuentro con sus connacionales se verifica en el reducido número de testigos de ese origen que certificaron conocerlo luego de su muerte. En rigor, apenas dos, cuyos nombres de pila fueron castellanizados en los documentos uruguayos como lo fue también el del difunto, según era el régimen habitual en el derecho uruguayo que empezaba a ganar un amplio cuerpo normativo. Esos dos testigos fueron el dueño del hotel, Augusto Haurie, sobre quien nos detendremos más adelante, y Carlos Vasseur. Este informa de sí: "casado, panadero, de cincuenta y cinco ańos y con treinta y cinco de residencia", declara luego "su amistad con el finado Ducasse", y ya no aparece más (AGN/AJ, 1889, folio 23).

Curiosamente nunca figura entre los muchos declarantes circunstanciales un compatriota a quien Haurie debió conocer muy bien, ya que era coetáneo de su cliente y frecuente visitante del hotel: Prudencio Montagne. Mucho tiempo después, este anciano le aseguró a su sobrino, el escritor Edmundo Montagne (nacido en Montevideo pero radicado muy joven en Argentina), que él era la única persona que acompañaba al canciller en los días finales, que lo llevaba a almorzar los domingos a su casa y que solían visitar la cervecería de un compatriota de apellido Thiébaut. Recordó, también, que hasta dos 
días antes de su muerte tomaban mate en la pieza del hotel, muestra del inevitable acriollamientode los dos viejos migrantes (PICHON-RIVIËRE, 14/IV/1946, p. 2).

Eran esos tiempos de calma y de férreo control; tiempos propicios para los paseos de dos personas mayores que no se metían en política local y disfrutaban de un muy buen pasar. En efecto, la llegada del militarismo estabilizó la economía del país y fomentó la prosperidad de los capitalistas. Entre 1876 y 1885 la balanza comercial "dejó un saldo positivo de casi 15 millones de pesos, equivalentes a un presupuesto nacional" (BARRÁN; NAHUM, 2002, p. 41). Pero la inestabilidad del gobierno del general Máximo Santos, penúltimo del ciclo militarista, hizo retraer la inversión. Después de la la precipatada caída de Santos, en 1886, esos capitales retenidos se volcaron a "la realización y especulación" inmobiliaria, impulso que acompañó la obra pública (PIVEL DEVOTO; RANIERI DE PIVEL, 1966, p. 359). Inversionistas arriesgados, como Emilio Reus, impulsaron barrios como el que se conoce por el nombre de este español, que empezó a construirse en marzo de 1888 y para el cual fueron empleados hasta dos mil obreros por día, la mayor parte de ellos llegados de ultramar (FERNÁNDEZ SALDAÑA, 1967, p. 93). Poco más de esa cifra sería el total de los trabajadores manuales en Montevideo cuando la conoció François Ducasse. En efecto, la ciudad había dado un salto considerable. Un censo riguroso que se llevó a cabo el mismo año de la muerte de M. Ducasse probó que sólo en la planta urbana se había extendido de 7.164 edificios en 1872 a 18.174 diecisiete años más tarde, un aumento del 253\% (CASTELLANOS, 1971, p. 178).

Rumbo al fin de siglo Montevideo abandonaba su cansino paso colonial mientras Ducasse abandonaba la vida, pero estaba lejos de ser una gran urbe. En 1880 se había iniciado la demolición del Fuerte, donde se construyó la plaza que homenajea al fundador de la ciudad, Bruno Mauricio de Zabala (CASTELLANOS, 1971, p. 165). Eso, a unos quinientos metros de la residencia del canciller casi en línea recta. El estruendo y la polvareda deberían ser arrastrados por los movimientos circulares que el viento acostumbra en la península hasta alcanzar la residencia del anciano. Hacia el otro lado, al este de la ciudad, a partir de la actual calle Eduardo Acevedo, dominaban las chacras y los campos. Casi a la misma altura, pero por la calle hoy 
llamada Constituyente, las construcciones alineadas llegaban hasta la calle Magallanes, ubicada a menos de tres mil metros de la plaza Matriz y de la vivienda última de M. Ducasse. Pronto, por toda esta área, la construcción tomaría un gran impulso de la que todavía hay numerosas muestras.

Ducasse era uno de los especuladores inmobiliarios de fines de los ochenta. No de los más fuertes ni de los más significativos. Otros datos extraídos del expediente que nos ocupa de modo fundamental, que hasta ahora no se han difundido, revelan que vivía de su respetable jubilación consular, de las rentas que recibía de sus depósitos en instituciones bancarias de Uruguay y Francia, pero también de los intereses por los préstamos que hacía a particulares no necesariamente regulados por las autoridades. El arqueo hecho por disposición judicial el 25 de noviembre de 1889 puso de manifiesto papeles de crédito y deuda, títulos de venta unificada, acciones del Banco Comercial y del Nacional de Montevideo, así como títulos de algunas propiedades en esta ciudad. El retirado canciller había amasado una pequeńa fortuna, que siguió aumentando y cuidando a partir de diversas operaciones, incluso hasta muy poco antes de morir (ver Anexo I).

El dinero era una pasión que mantenía en el mayor sigilio; tanto, que los hermanos Guillot Muñoz, quienes llegaron a conocer a muchos de sus contemporáneos, en su ensayo pionero de 1925 afirmaron que M. Ducasse había muerto en la pobreza, aunque rectificaron el error en el posterior trabajo "La leyenda de Lautréamont" (GUILLOT MUÑOZ, 2009 [1935]). En esa misma trampa había caído el propio redactor de la nota que da cuenta de la muerte con las últimas luces del 18 de noviembre del 89. Es seguro que el oficial actuante escribió su breve informe en base al testimonio del propietario del hotel, M. Haurie. A su superior dijo que al fallecido "no se le conocen bienes de fortuna", y que no se sabía de otros herederos salvo "de un hermano en el Rosario de Santa Fé" (AGN/AJ, 1889, folio 10), otro dato erróneo que por distracción el propietario del hotel trasmitió al oficial confundiendo una ciudad argentina (Córdoba) con otra (Rosario). En declaración posterior-como veremos- Haurie dice haber conocido a los parientes de su huésped. 
El único hermano vivo del canciller que aún estaba en tierra americana se llamaba Bernard-Lucien y andaba por los setenta y seis años en ese momento. Otro descenciente era su sobrino Doctrové, hijo del extinto Jean. Hermano y sobrino sabían muy bien que don François tenía "bienes de fortuna". Tanto que, apenas diez días después ya estaban en Montevideo, adonde llegaron porque debieron recibir un telegrama (tal vez enviado por el mismo Haurie) y se apresuraron a emprender un muy largo viaje desde la lejana Córdoba en tren hasta Buenos Aires, y de ahí en barco hasta tocar puerto de Montevideo. Tío y sobrino se instalaron en el mismo hotel donde falleció François Ducasse. Sin demoras contrataron los servicios de un prestigioso representante legal uruguayo para iniciar el juicio del que obtendrían buenos resultados.

\section{III}

François y su mujer convivieron un par de ańos en una agónica ciudad. Céleste Davezac había llegado en 1841 y allí falleció el 9 de diciembre de 1847, en lo más crudo del sitio, tres semanas después del bautismo de su niño. El único sobreviviente de la estricta familia, muerto Isidore en 1870, parece haber disimulado muy bien su dolor. No se sabe (o no pudimos averiguar en fuente alguna) si este hombre de buen porte y mejor posición económica mantuvo algún vínculo afectivo prolongado desde entonces, aunque con menos de cuarenta ańos de edad se quedó solo y a cargo de un bebé. Se ha dicho que era aficionado a las actrices y que, antes de su matrimonio, había tenido una relación con una bailarina española (GUILLOT MUÑOZ; GUILLOT MUÑOZ, 1925, p. 18). Los libros del Cementerio Central avisan de la enigmática presencia de varias mujeres enterradas en su tumba, dos de ellas madre e hija, la última fallecida a los tres meses y medio de edad (GUILLOT MUÑOZ, Á., 1972, p. 100-101). Se lo ha recordado de baja estatura y en algún momento de su vida como "elegante, fino, burlón y escéptico, dueño de una gran cultura literaria” (PICHON-RIVIÈRE, 14/IV/1946, p. 2).

Después de la muerte de su joven mujer no parece haber pensado volver a su país de origen, adonde hasta donde se ha indagado por el momento habría viajado mucho después, en una sola ocasión, 
en 1873, es decir a tres años del fallecimiento de su único hijo. Montevideo era un lugar tan suyo como el rincón de la lejana Francia del que provenía, pero se había convertido en el lugar del dolor. Una vez jubilado del servicio pudo haberse radicado en la Córdoba adoptada por sus hermanos, donde hoy una calle bastante céntrica los recuerda, quizá más por la importancia de su molino harinero que por los méritos particulares de sus propietarios. Allí pudo encontrar un refugio y una cercanía afectiva con los suyos. Tenía una buena relación con ellos. Habían llegado juntos hasta esta región del mundo y luego del fin de la Guerra Grande, ocurrido en 1851, algunos de sus parientes lo habían visitado al menos una vez, como se desprende con claridad de las declaraciones presentes en el expediente que nos ocupa. Pero François Ducasse eligió quedarse solo y en la capital uruguaya. Se refugió en su trabajo consular, alternó con sus contemporáneos en tertulias y algún café, confitería o cervecería, concurrió a los espectáculos teatrales. Sus jerarcas tenían una excelente opinión sobre su desempeño, como la que expresó sin ambages al ministro francés el agudo Martin de Mailleffer, cónsul en Montevideo: "El Sr. Ducasse, primer comisario de la Cancillería, que ya ha cumplido por dos veces honorablemente el interinato, se ha hecho cargo con mi autorización, del servicio y la firma a partir del $1^{\circ}$ de julio [de 1854]" (MAILLEFFER, 1962, p. 580 [4/VII/1854]). Sus años de soledad se ahondaron desde 1857 cuando envió a su hijo de poco más de trece ańos para que estudiara en colegios de su tierra de origen, donde nunca lo habría visitado.

Se ha manejado muchas veces una presunta visita de Isidore a Montevideo en 1867. En ese momento, François Ducasse seguía en actividad. La legación de su país estaba en el número 32 de la calle Solís. Ducasse seguía residiendo en Camacuá No 9, a unos metros de la calle Brecha, puerta por medio del domicilio del escritor y reconocido periodista Isidoro de María. Allí había nacido su hijo y sólo una foto publicada por los Guillot Muñoz, tomada por 1920, registra esa casa de rústico estilo colonial español, seguramente bastante espaciosa a juzgar por las dimensiones de su frente y según el recuerdo de algunos testigos que consultaron estos mismos acuciosos investigadores. Unas once cuadras debía recorrer el funcionario diplomático para llegar a su trabajo. El estado de las calles y veredas no era el mejor. 
En los años veinte del pasado siglo todos los predios de la acera sur de la calle Camacuá fueron demolidos para construir la rambla. Cuando nadie imaginaba tal obra pública, un hombre anciano que se había retirado sólo podía ampararse en una habitación de hotel para pasar los días que le quedaban o, en su caso, encerrarse en la vivienda azotada por el viento del sur rodeado por alguna servidumbre que lo atendería. Aunque su longevidad lo desmienta, ya que falleció con ochenta años -cifra entonces extraordinaria-, quizá su salud ya estuviera afectada mucho antes del fin. En 1862, según los Guillot, se enfermó de paludismo en un aventuresco viaje al Paraguay (GUILLOT MUÑOZ; GUILLOT MUÑOZ, 1925, p. 18-19). Es probable que esa versión integre la leyenda. En cambio, está probado que al borde de los sesenta ańos su salud padeció un golpe fuerte cuando contrajo el cólera durante la terrible epidemia de este virus, que sobrevino en Montevideo durante el febrero amargo de 1868, duro traspié también informado por su superior a las autoridades ultramarinas. ${ }^{6}$

El natural debilitamiento ocasionado por el paso de los años debió persuadirlo de que era mejor acercarse al epicentro de la ciudad vieja antes que subir, trabajosamente, la empinada cuesta que conduce hasta ese lugar. En particular, pudo querer salir del aislamiento con la sola vecindad del mar inhóspito y embravecido en el frío invierno. Ese mar del que tantas veces se ha dicho que pudo inspirar a su hijo para imaginar el "viele océan" de Les chants de Maldoror.

\section{IV}

Montevideo tenía muchos hospedajes de toda clase, en especial fondas de tipo español -veintiuna en 1859-, donde se podía

6 Acerca de los terribles acontecimientos políticos en Uruguay durante febrero del 1868, sobre los que no podemos detenernos aquí, véase Real de Azúa (1987). El canciller Maillefer informó a su ministro el 14 de marzo de ese año que "Una de mis hijas y el Sr. Ducasse caían enfermos al mismo tiempo. Han escapado, gracias a Dios, pero este último no ha podido, durante casi quince días, cumplir con sus activas funciones en mi Cancillería" (MAILLEFFER, 1956, p. 314). Sin saber que estaba publicado y traducido al español, Lefrère citó parte del documento en el original: «François Ducasse ne fut pas épargné par la contamination, comme il ressaut de cette lettre du 14 mars 1868 du consul Maillefer à son ministre du moment, le marquis François-René de Monstier: [...] Une de mes filles et M. Ducasse son tombés malades en même temps. [...] mas ce dernier n'a pu, durant quinze jours, remplir ses fonctions dans mon consulat» (LEFRÈRE, 1998, p. 299-300). 
pernoctar y alimentarse. Desde el fin de la Guerra Grande, ocurrido el 8 de octubre de 1851, los hoteles comenzaron a brotar gracias al crecimiento de la ciudad bajo el curso de una pacificación que facilitó el comercio con un puerto abierto y apto. Para 1870 el eje de la ciudad se estaba moviendo unas cuadras desde la Plaza Matriz o Constitución hacia la Plaza Independencia. A su alrededor emergió el conjunto hotelero más numeroso y moderno: el Barcelona -en la acera norte, de dos plantas-, el France, el Universo, el hotel del Plata, el Ferro-carril, el Independencia y el "Malakof, de Guillermo Aldaxe, No 1 de 18 de julio, en la esquina donde [desde 1929] se levanta la torre del Palacio Salvo" (FERNÁNDEZ SALDAÑA, 13/VIII/1944).

M. Ducasse tenía que elegir zona y hotel y disponía de un buen repertorio. En lugar de la despejada ciudad nueva prefirió la parte antigua donde había pasado casi toda su vida adulta, una zona más compacta, abrigada y todavía más elegante. Como se dijo, debió distanciarse del mar para cubrirse del viento inclemente. Pudo, de lo contrario, haber alquilado una habitación en el majestuoso Hotel Oriental en el extremo opuesto al de su casa. Era el mejor alojamiento ocasional de los que había en la época, una construcción de grandes dimensiones y de dos pisos, que se terminó en 1865 y que permanecerá hasta su demolición completa, menos de medio siglo después, para que ocupara su sitio la casa central del Banco de la República Oriental del Uruguay, donde hasta hoy funciona. Había otras alternativas de residencia elegantes: el Gran Hotel Americano, situado a unas cuadras del mar, en Cerrito y Misiones, sólido y amplio edificio de tres pisos (demolido hacia 1945) o el más modesto, pero muy nuevo, Hotel Espańol, inaugurado en 1872 en la calle Bacacay, a media cuadra del Teatro Solís; o el Hotel de la Paz, propiedad de su coterráneo Adrián Poupart, establecimiento que -según Fernández Saldaña- se destacaba por su decoración floral en corredores y balcones. Antes que todas estas opciones M. Ducasse eligió la cercanía de la vieja plaza, más protegida, equidistante del mar y de la energía del viento, situada a cuatrocientos metros de la que había sido su última casa. Allí dejó de tener el horizonte a su alcance, pero evitó el cerco de las interiores calles estrechas de la ciudad antigua o el límite visual de las azoteas de tipo español. 
A un paso de la Plaza Constitución, que ya contaba con su hermosa fuente de mármol, inaugurada en 1871, y a la que por entonces se le habían cortado los árboles que fueron restituidos veinte años después, estaba el Hotel des Pyramides. De todos los muchos hoteles ya nombrados es el único que subsiste. Ducasse lo eligió como hogar, y desde la ventana de la habitación número 9, en la que vivió durante una década, podía ver un amplio ángulo de la plaza. Fernández Saldaña informa que con ese nombre el establecimiento se había iniciado en 1855 como café y restaurante, ya con una entrada por Sarandí y otra por Ituzaingó. Sin perder el restaurante, agregando un piso, el hotel "abrió al público el $1^{\circ}$ de noviembre de 1874" (FERNÁNDEZ SALDAÑA, 13/VIII/1944), en el mismo lugar en que aún está, felizmente reformado en 2008 luego de vivir una larga y penosa caída. En el Instituto de Historia de la Arquitectura (Universidad de la República), no existen "los planos originales ni material relevante" de este edificio, según nos informa la arquitecta Laura Alemán. El edificio está protegido desde 1986 cuando fue declarado monumento histórico nacional con el "Grado 4 de protección (el máximo asignado)". La ficha detalla que el predio tiene 387 metros cuadrados; imprecisamente avisa que se construyó "a mediados del siglo XIX", que "se agregó a comienzos del siglo XX" un tercer piso y que sus marquesinas fueron reformadas en $1906 .^{7}$ En ese documento no se aclara si el edificio se construyó para el hotel ni qué tipo de construcción había antes en ese lugar. A falta de mejores datos catastrales podemos servirnos de viejos registros iconográficos, que en el caso se vieron favorecidos por la frontería del predio con la catedral, el más alto de la ciudad hasta que se terminó de levantar el primer rascacielos del sur de América: el Palacio Salvo.

Una pequeña litografía firmada por Lauvergne y editada en Londres en 1836 se focaliza, justamente, en la catedral. Aunque un poco oculta tras una carreta con sus correspondientes bueyes se nota

7 Debo estos datos a la arquitecta Laura Alemán, quien en mensaje electrónico del 17 de mayo de 2016 me informó que el Instituto de Arquitectura preserva dos recientes artículos de prensa sobre el hotel, además de la ficha del edificio incluida en el Inventario de Ciudad Vieja realizado por SAU-IMM en 1983. (IHA Carpeta 1612/7). La ficha online del edificio está incluida en el Inventario de Ciudad Vieja realizado por IHA-IMM en 2010 (actualización del anterior). Disponible en <http://inventariociudadvieja.montevideo.gub.uy/padrones/4267>. 
una casa grande y tosca, de una sola planta, donde algunos lustros después se erigió el Pyramides (ICONOGRAFÍA..., 1955, p. 176). Pudo ser una casa-habitación o tal vez, por la privilegiada esquina que ocupaba, un comercio o hasta un alojamiento circunstancial. La vecina catedral hizo que muchos dibujantes siguieran reparando en ese punto sobre todo cuando se erigió el hotel, quizá más interesados en ese ángulo de la plaza, por la calle Ituzaingó, que en el opuesto, justamente por el encanto y el porte de este edificio. Un colorido dibujo de F. Soneira, de 1855, ya encuentra al edificio completo, con mirador incluido en el tercer nivel. Lo mismo se ve en posterior grabado de R. Meyer, publicado en el periódico El Americano, de París, en 1873, en el que se registran claras las líneas de un predio flamante. Aunque la catedral lo duplica en altura, el hotel se luce en la chata ciudad ya que, en perspectiva, los trazos del grabador sólo hacen asomar la cabeza de unas pocas casas, como la del Gral. Fructuoso Rivera, en la calle Rincón, y la del Hospital de Caridad, luego y hasta hoy Hospital Maciel. Más nítido aún el Pyramides aparece en un limpio grabado de Giosué Bordoni, editado en Milán en 1885, en el que se destacan las altas puertas y ventanas de la planta baja, que terminan en un arco de medio punto, y los numerosos balcones de hierro forjado de los dos pisos superiores. Bordoni lo vio en el preciso momento en que allí habitaba Ducasse, y así debió permanecer hasta la muerte del antiguo funcionario diplomático (ICONOGRAFÍA..., 1955, p. 231; 255). Por último, existe una fotografía que ilustra el mencionado artículo de Fernández Saldańa, que si bien capta un fragmento del edificio confirma esas características percibidas por el trazo del artista italiano (FERNÁNDEZ SALDAÑA, 1946).

M. Ducasse conoció tres estadios de la vida de la ciudad Montevideo: el que pugnaba por salir de la reseca existencia colonial española; el que debió atrincherarse durante casi ocho años cercado por un poderoso ejército y sufrió las consecuencias de esa lucha; el que creció lenta pero sostenidamente desde fines de los ańos cincuenta hacia la modernización que alcanzó a tocar. El 25 de agosto de 1886 sin moverse de su pieza pudo ver la inauguración de la iluminación eléctrica de toda la Plaza Constitución que tenía a escasos metros (CASTELLANOS, 1971, p. 173). 
La desaparición del archivo del hotel nos priva de la fecha exacta en que M. Ducasse se radicó allí. Sin muchos elementos a la vista Jean-Jacques Lèfrere estimó que el traslado sucedió entre 1875 y 1880. El legajo sucesorio aporta una información más precisa, ya que prueba que M. Ducasse llegó al hotel entre fines de 1878 y principios del siguiente ańo luego de que, previsiblemente (o eso creemos) hubiera vendido la casa (no sabemos a quién) de la calle Camacuá, donde había nacido su hijo y él había vivido unos treinta años. En la decisión también debió pesar su cercanía al propietario del Pyramides, Auguste Haurie, quien tenía casi la misma edad de Isidore, y con quien todo indica que el anciano tenía una relación fraterna, si bien sabía mantener sus secretos, por ejemplo el de su abultada cuenta bancaria y de sus operaciones como prestamista. En oportunidad del deceso de su antiguo cliente, Haurie declaró ante la justicia ser "francés, casado, comerciante de cuarenta y cinco ańos, y con 19 de residencia" en el país; dijo que vivía con su familia en el hotel y que

\section{[...] conoció a don Francisco y conoce [...] a don Luciano hermano de aquel y Don Droctové sobrino de ambos lo que le consta por haberlo oido al finado don Francisco y haber visto que los trataba como tales, durante más de diez años que el finado vivió en el hotel de las Piramides[,] propiedad del declarante (AGN/AJ, 1889, folios 22-23).}

Por el testimonio de M. Haurie, como se anunció, podemos saber que los parientes del canciller estuvieron por la capital uruguaya poco tiempo antes de la muerte de François Ducasse. Quizá hayan viajado los casi mil kilómetros que separan Córdoba de Montevideo sólo en vísperas de la redacción del testamento, escrito en francés y datado en 1881 (folio 8A), en que M. François Ducasse los favorecía con sus bienes en caso de producirse su deceso. El original manuscrito fue hallado en la habitación, se incluyó en el expediente y del mismo había copia en la legación francesa, valioso documento que a partir de esta última fuente reprodujo Lefrère por primera vez. Pero un texto manuscrito y en otra lengua que no fuera la castellana no tenía validez jurídica en Uruguay. El grave percance dilató la toma de posesión de esos bienes por parte de los Ducasse franco-cordobeses. Con todo, la existencia de ese documento debió gravitar a su favor en los ánimos 
del juez y del fiscal para conseguir lo que buscaban y lo que, al cabo, les correspondía, al no haber otro heredero o beneficiario a la vista. Para esa emergencia los favoreció la genealogía de la familia que detalló el doctor Aramburú en muy buena prosa, la cual nos permite hoy averiguar ciertos datos ignorados sobre distintos integrantes de ese apellido disperso por dos continentes (ver Anexo III).

Volvamos al hotel de tan exótico nombre, al que su diseño hace modesto homenaje. Concentrémonos en un entorno compuesto por los mejores espacios de recreo y alimentación de los que disponía la ciudad. En el inventario levantado a "veinticinco de noviembre de 1889" aparecen "gemelos para teatro". Ducasse, que había conocido el nacimiento de un teatro en que la colectividad francesa había tenido una fuerte incidencia, formado por compañías de aficionados que durante la guerra realizaban funciones sobre las que avisaba con precisión el diario de la colectividad Le Patriote Français; Ducasse, que había tenido que asistir a salas improvisadas en casas acomodadas a tales efectos o al Teatro San Felipe o Coliseo, algo más que un gran galpón ubicado donde hasta hoy está el Palacio Taranco (ARDAO, 1973-74), en un radio de quinientos metros ddesde 1856 pudo asistir a las funciones del gran Teatro Solís, que se encontraba en su apogeo hacia 1880 (CASTELLANOS, 1989) o al Nuevo Teatro San Felipe, refundado en 1880, que contaba "con café y confitería en la planta baja" (CASTELLANOS, 1971, p. 166) o al Teatro Cibils, situado en la calle Ituzaingó entre Cerrito y Piedras, en cuyo vestíbulo, en 1886, se producirá el atentado contra Máximo Santos que lo obligará a retirarse de sus funciones.

En los recuerdos de Prudencio Montagne hay paseos con su adusto amigo, a quien evoca siempre vestido "de levita" y ostentando "galera de felpa" (PICHON-RIVIÈRE, 14/IV/1946, p. 2). Las levitas, rigurosamente negras, abundan en el inventario final, pero no hay galeras ni sombreros. M. Ducasse debía acompañar su marcha, por refinamiento o por necesidad, con uno de los dos bastones que lo sobrevivieron. La soledad de las calles que daban al mar, a pocas cuadras de la ubicación del hotel, contrastaba con el murmullo del ir y venir de la gente cerca de la Matriz, lo cual debió dulcificar su vida última. Daniel Muñoz revivió ese cuadro en Cristina, una nouvelle romántica, estilizada y olvidadísima, publicada en 1885: 
En la Plaza Constitución era más activo el movimiento y más bullicioso. Por todas las aceras se veían grupos de señoras que iban a la Matriz, cuyas empinadas torres hendían la atmósfera azul que envolvía a la ciudad, reverberando en sus cúpulas de porcelana los rayos del sol radiante que doraba todas las cornisas y pretiles de las azoteas (MUÑOZ, 1885, p. 6).

Una de esas azoteas doradas era la del Pyramides.Aunque por los tiempos en que falleció M. Ducasse los hermanos Guillot digan que el hotel era sede de "veladas políticas y literarias" (GUILLOT MUNOOZ; GUILLOT MUÑOZ, 1925, p. 19), no tenemos información precisa sobre unas u otras. Pero es probable que el restaurante por su ubicación céntrica y su porte distinguido, para los parámetros de la época y el lugar, facilitaran esos encuentros. Por lo demás, los años dorados del hotel aún estaban lejos. Su brillo llegó por 1910 y por entonces se construyó el mentado tercer piso, al amparo de esa prosperidad que en crónicas y hasta en monografías importantes se confunde con las primeras décadas.

Visitada por Lefrère un siglo después de la muerte de Ducasse, la habitación en que pasó la última década de vida le pareció al investigador "sombre, triste et crasseuse" (LEFRÈRE, 1998, p. 623). En verdad, hacia 1880 las características arquitectónicas de los grandes hoteles de esta ciudad no favorecían una mayor amplitud y luminosidad. Por lo demás, el deterioro en el que se sumergió hacia 1970 fue de grandes proporciones. El Pyramides conservó su nombre y perdió todo su fulgor, volviéndose pensionado, fragmentándose en apartamentos de bajísimo costo y mala reputación. Esa realidad que ocultaba hasta la sombra de un remoto prestigio debió deprimir al investigador. $^{8}$

8 En la primavera de 2001 intenté visitar el hotel. Alguien estaba en la portería, en un hall amplio y detrás de una cabina en forma semicircular cubierta de vidrios en la parte superior. Había un amplio mostrador de madera. En el lado opuesto, a unos cuatro metros alcancé a ver una escalera bastante ostentosa en forma de arco, por la que bajaba una pareja vestida como si salieran de una película de Fellini: un hombre de bajísima estatura y edad avanzada, con traje negro y sombrero hongo de igual color, del brazo una mujer algo menor en edad con un vestido blanco. Puede que la impresión de aquella sala decadente adornen el recuerdo. Con algunas secas palabras no se me autorizó a entrar. Me dio toda la impresión de que el conserje o portero (desprovisto de cualquier uniforme), quien estaba 
En rigor, en una habitación de reducidas dimensiones poco se podía albergar. El inventario de los bienes del difunto prueba que no conservó un solo mueble, ni un cuadro o un adorno valioso de los varios que tenía en su primera casa, la de la calle Bacacay, según ajustada evocación del arquitecto Masquelez (GUILLOT MUÑOZ; GUILLOT MUÑOZ, 1925, p. 20). Resignado, austero y tal vez algo vencido, François Ducasse se instaló en su domicilio definitivo con un puñado de recuerdos $y$, principalmente, con su ropa en la que dominaba el color negro, signo de un doble y prolongadísimo luto. El recuento final no hace referencia a imagen alguna: no hay dibujo o daguerrotipo de su mujer ni fotografía de su hijo ni de nadie de su familia, ni siquiera de él mismo, aunque un retrato en forma de medallón debió pasar a sus herederos que se lo proporcionaron en 1946 a Pichon-Rivière, quien lo publicó por primera vez. Quizá estos elementos fueron englobados en un amplio "etcétera" en la carpeta del inventario que refiere a papeles privados. Una foto, entonces, era algo que no podía pasar inadvertido porque era un objeto bastante infrecuente. El relevamiento judicial, quizá siguiendo una rutina en la que la imagen aún no tenía el peso que ganaría en el futuro, privilegió la letra y lo que se entendía de valor. Se jerarquizó lo tangible, porque se anotó con minucia cada objeto, cada prenda, hasta la ropa interior y-qué extraño- un solitario par de botines.

\section{V}

Si François Ducasse era aficionado a las letras y a la filosofía, los últimos tiempos dejó de serlo activamente. ${ }^{9}$ A pedido de

leyendo un diario, recibía molestas visitas frecuentes como la mía. Bajó la cabeza y me olvidó en el acto.

9 Los Guillot Muñoz apoyados en el testimonio de un contemporáneo francés afirman que François Ducasse, al regreso de su hipotético largo y arriesgado viaje por el "Alto Paraguay", fundó "una escuela de lengua francesa, en la que él mismo dictó un curso de conferencias sobre filosofía. Ante lo más escogido de la intelectualidad montevideana, expuso en ese colegio la influencia de Comte y del positivismo fuera de Francia y comentó las ideas morales de Edgard Quinet" (Cit. por GUILLOT MUÑOZ, 1974, p. 21). En realidad, como lo probará el mayor historiador de las ideas en Uruguay, el doctor Arturo Ardao, el positivismo había sido introducido mucho antes de esos comienzos de la década del sesenta a que, vagamente, aluden los hermanos Guillot. Pero lo más curioso es que en los eruditos estudios de Ardao las conferencias de Ducasse nunca son mencionadas. 
los Guillot, el arquitecto Masquelez recordó varios títulos de libros y periódicos que su amigo tenía en la sala de la casa de Bacacay en el entorno de 1840 (GUILLOT MUÑOZ; GUILLOT MUÑOZ, 1925, p. 20; GUILLOT MUÑOZ, Á., 1972, p. 67). En 1889 según el arqueo de sus bienes sólo había en su pieza "tres libros encuadernados", cuyos títulos no se revelan. Un año después, en oportunidad del remate, se detalla que uno de esos libros es el Diccionario Universal, mientras se encierra en un breve lote a dos "libros en francés". Por el primero alguien pagó setenta centésimos; por los segundos, apenas treinta centésimos, o sea quince centésimos por cada uno, el mismo ridículo precio que se pagó por cinco pares de medias usadas... dos años atrás. No sabemos si François Ducasse eligió para su compañía final a Les chants de Maldoror. Parece difícil. Veamos por qué.

Todo parece indicar que es difícil que algún objeto que haya pertenecido a Isidore Ducasse permaneciera en la habitación que ocupó su padre en sus últimos días. Nada de lo inventariado resulta evidencia clara de su pertenencia. Por lo demás, todo lo poco que tenía el viejo canciller fue rematado en diciembre de 1890, y aquello que no se dispersó entre los varios ofertantes fue robado del depósito judicial, según informa el mismo responsable de la custodia de esos bienes (ver Anexo II). Entre la papelería se cita una "libreta de apuntes", un "legajo de papeles, cartas, recibos, etc." y un "diploma de bachiller", quizá este pudiera haber sido de su hijo, quizá el único recuerdo preciso. $\mathrm{O}$ tal vez podía ser del propio François Ducasse, porque no hay descripción precisa del "legajo de papeles, cartas, recibos, etc.". Como si cualquier ensayo por asir la imagen de Isidore, en cualquiera de sus formas, una y otra vez se escabullera a nuestros intentos de ubicarla.

En una nota posterior al inventario, afanosos por obtener los bienes del fallecido y ansiosos por volver a casa, su hermano Bernard-Lucien y su sobrino Doctrové, citan como legítima prueba de sus derechos "las propias cartas nuestras que existen [...] entre los papeles judicialmente inventariados" (AGN/AJ, 1889, folio 17). La afirmación demuestra que han tenido prematuro acceso a documentos que, se supone, estaban en reserva hasta tanto hubiera resolución judicial, por lo que se corrobora que no sólo casi todos los testigos

Aun más, su nombre nunca aparece relacionado con corriente filosófica alguna (ARDAO, 1962; 1968; 1971). 
(para empezar el fundamental Haurie) eran proclives a que la sucesión recayera pronto en los parientes franco-cordobeses, sino que los actores judiciales uruguayos se avienen a facilitar cualquier prueba a los reclamantes. Difícilmente se hayan olvidado de que había otra heredera, Lucia o Lecea Ducasse de Suárez, quien pese a la retracción de su tío y su primo llegó a enterarse del asunto y pudo entrar tardía, aunque exitosamente, en la sucesión para conseguir la parte que legítimamente le correspondía.

Si hubo un epistolario entre François y su hijo, que no pudo sino haber existido, debió estar en ese impreciso legajo. Si estas cartas se conservaron durante el proceso debieron pasar, luego, a poder de sus parientes. En Córdoba, en 1946, Pichon-Rivière recabó la impresión de diferentes testigos que conocieron a los Ducasse como personas rígidas, muy religiosas, poco sociables y harto dedicadas a su molino harinero y sus comercios, celosos por sus bienes de fortuna que los del pariente de Montevideo ayudó a incrementar. No es una novedad que la familia de Isidore prefirió olvidarlo. Sus tíos y primos debieron horrorizarse ante la noticia, la sospecha o la lectura de que su joven y fallecido pariente había escrito textos blasfemos. O simplemente el olvido, que arrebata a los próximos y mucho más a los lejanos, hizo su obra destructora. Lamentablemente los hermanos Guillot Muñoz no viajaron a la antigua capital de la provincia argentina cuando a comienzos de la década del veinte comenzaron sus indagaciones sobre Lautréamont. Un cuarto de siglo les hubiera dado una ventaja. Aun así, es difícil que estuvieran a tiempo de rescatar papeles que, con seguridad, desde hacía varias décadas se habrían tornado cenizas.

Se ha conjeturado más de una vez que la posición económica holgada de su padre pudo haber facilitado la vida de Isidore en Francia, y hasta que pudo servirse de ese dinero para la edición de sus obras. Así debió ser. Como también se ha documentado que el joven poeta vivió en Francia en lugares decentes y estudió en colegios costosos, para lo cual necesitó de los fondos que venían de ultramar. Parece claro que M. Ducasse no soportó la tan prematura muerte de Isidore o no se perdonó su conducta durante tan prolongado lapso en que no lo vio, tantos años en que dejó solo a quien ni siquiera llegó a ver morir. Cabe postular, por eso, que su salvación personal fue reprimir la memoria de su hijo. Sabemos por una evocación de Daniel Muñoz, 
fechada en 1924, de la que sólo se conoce la versión en francés, que el anciano Ducasse a quien veía con cierta frecuencia "ne parlait jamais de son fils, qui était devenu une sorte de tabou" (GUILLOT MUÑOZ, Á., 1972, p. 40). Sabemos que el anciano mencionó una sola vez a Isidore en las conversaciones con su confidente Montagne, a quien le comentó que su hijo había muerto en 1870 , pero no habló de la causa de la muerte ni del lugar donde ocurrió. Reserva de tales proporciones hizo creer al interlocutor que el muchacho había caído "en la guerra" (apud PICHON-RIVIÈRE, 14/IV/1946, p. 2). Es decir, que había sido abatido en la guerra franco-prusiana que estalló ese año o, quién sabe si la confusión se extendió aún más, el interlocutor frecuente hasta pudo pensar que Isidore murió en el conflicto civil uruguayo que estalló el 5 de marzo de ese ańo, conocido como la "Revolución de las lanzas", y que siguió hasta que se firmó la paz el 8 de abril del 72 (CASTELLANOS, 1977).

El dueño del hotel y algunos testigos declararon que $\mathrm{M}$. Ducasse era viudo. Varios, como Auguste Haurie, dijeron conocerlo desde muchos años atrás; otros, el comerciante Bruno Carril y su empleado Juan Bolasco, testigos inmediatos de la defunción de François Ducasse ante el Juzgado de Paz de la tercera sección de Montevideo "hacen constar que [...] conocían simplemente al finado y que ignoran todo otro dato" (AGN/AJ, 1889, folio 4). Ninguno de los dos aparece nunca más en esta historia para la que fueron convocados probablemente por el mismo oficial de policía que quería cerrar el procedimiento lo antes posible. Esa radical soledad podría explicar que nadie diga nunca que el habitante de la pieza No 9 del Hotel des Pyramides había tenido un hijo, y que ese hijo estaba muerto. No obstante, tal información era decisiva para el proceso iniciado a falta de la validación del testamento escrito en francés por M. Ducasse, en el que tampoco menciona la falta de su hijo y en el que cede lo que quedará a su muerte a los familiares radicados en Argentina.

En un legajo de aproximadamente nueve mil líneas manuscritas la historia de Isidore ocupa ocho. Se lo invoca por ausencia, para remarcar su desaparición como causahabiente y, de paso, asociado a su madre, para descartar la existencia de otros hijos legítimos. Aunque se remite a la partida de nacimiento, por evidente error esa fecha se adelanta un año: 
[...] del matrimonio entre D. Francisco Ducasse y Da Celestina Jacquet Davevac (sic), nació en esta ciudad el 4 de Abril de 1847 un hijo legítimo llamado Isidoro Luciano -partida No 1. Que ese hijo, Isidoro Luciano Ducasse, falleció en Paris el 24 de noviembre de 1870- Segunda partida del octavo legajo.

Con estos documentos y con lo que resulta de la información de $\mathrm{f}$ [en blanco en el original], queda plenamente comprobado que Don Francisco Ducasse era, á su fallecimiento, viudo y no tenía hijos ni descendientes legítimos (AGN/AJ, 1889, folios 301-302).

Toda indagatoria sobre el heredero universal se detiene allí. No se insinúa la posibilidad de que el joven fallecido en París hubiera podido tener descendencia. El redactor del exhaustivo informe, el doctor Pedro Aramburú, representaba a quienes venían de Córdoba (ver Anexo III), por lo que la investigación sobre la vida y sus eventuales descendientes, más que la indagación de la probada muerte de Isidore, tendría que haberla hecho la justicia uruguaya, a falta de querellantes o de otros interesados. Si se hubiera requerido información al Estado francés, en el improbable caso en que tal solicitud hubiera tenido eco, quizá tendríamos otros indicios sobre los últimos días de Isidore Ducasse. Pero tal cosa no sucedió. Lejos estoy de sugerir siquiera remotamente que Isidore haya tenido hijos. Digo, apenas, que podríamos saber algo más de su vida breve de haberse cumplido el debido proceso en todos sus términos. Ante la clara evidencia del gran ausente, el fiscal prefirió ignorar más trámites para corroborar o desmentir la hipótesis de un descendiente directo en tercer grado. Entonces, adoptó el punto de vista de los reclamantes y le sugirió al juez que cerrara la sucesión. Con ese acto se clausuró la historia de esa línea de los Ducasse en Montevideo.

En su informe, Aramburú remite a muchos documentos de prueba: partidas de nacimiento y de defunción y hasta el dibujo del árbol genealógico de los Ducasse. Ninguno de estos documentos se encuentra en el legajo sucesorio. $O$ están en otro expediente o en apéndice a este, cosa difícil, o se han extraviado, o alguien los sustrajo. Alguien había leído este corpus. Alguien tildó, con tinta azul, la 
primera referencia a los "tres libros encuadernados". Otro enigma a resolver. ${ }^{10}$

En un célebre ensayo sobre Kafka, Walter Benjamin anota que "el mundo de los funcionarios y el mundo de los padres es para Kafka el mismo. La similitud no los honra" (BENJAMIN, 2014 [1934], p. 24). Mutatis mutandis, donde el filósofo alemán escribe Kafka podríamos consignar Lautréamont. Si los otros enigmas siguen en suspenso ningún documento puede resolver este, cuya hondura empalidece cualquier acertijo y conduce a un abismo sobre el que la única respuesta hay que buscarla o, mejor, imaginarla en la literatura del Conde de Lautréamont.

\section{Referencias bibliográficas}

\section{Fuentes}

ARCHIVO GENERAL DE LA NACIÓN. AGN. Archivos Judiciales, Montevideo, 27/II/1886. María Arens de Ducasse c/Manuel Pereira (hijo), Legajo No 10/886. Libro 5º, No 15. [AGN/AJ, 1886].

ARCHIVO GENERAL DE LA NACIÓN. AGN. Archivos Judiciales, Montevideo, 18/XI/1889. Sucesión de Francisco Ducasse, Legajo

10 Los Guillot Muñoz ignoraron la existencia de este vasto expediente sucesorio. En ninguno de sus trabajos, escritos en colaboración o en forma de apuntes individuales, hay traza del mismo. Lefrère conoció mucha información de la que se aloja en esta papelería, pero a través de los documentos preservados en archivos franceses, sobre todo en los que corresponden a la legación de Francia en Montevideo. Sin embargo, la única vez que comuniqué una versión muy ajustada de este texto, el 8 de junio de 2018, en un congreso celebrado en Montevideo, un señor que no se identificó dijo -con irritación- que había consultado el documento, que había escrito una "biografía" aunque no aclaró si de François Ducasse o de su hijo o de los dos; dijo que había ofrecido su trabajo a varias editoriales sin éxito, y que por lo tanto está inédito, aunque dijo que lo "tenía registrado en la Biblioteca Nacional". Respondí que no estoy provisto del arte adivinatorio, que nadie conoce un texto si no está publicado, salvo confianza de su autor que para el caso, como era evidente, no existía. Ningún documento público tiene expresa reserva ni, menos propiedad intelectual alguna. Al cabo de la actividad el señor se retiró de la sala sin aportar otro testimonio, como si fuera parte de otro vuelo menor de Maldoror. Presenté la citada comunicación, que lleva el mismo título de este artículo, en mesa plenaria, que tuve el honor de integrar con los profesores Eric Walbecq y Kevin Saliou. Ocurrió la tarde del día mencionado en el marco del II Congreso Internacional de Literatura Francesa y Francófona, X Coloquio Internacional Montevideana, XXXI Jornadas de la Asociación Argentina de Literatura Francesa y Francófona, "Ducasse Maldoror Lautréamont. Mayo del 68. Erotismo, Sexualidad”, Montevideo, 7, 8 y 9 de junio de 2018, bajo la organización de la Dra Alma Bolón. 
No 13/1. Libro 16. Juzgado Letrado de lo Civil de 2 Turno. [AGN/ AJ, 1889].

ARREDONDO, H. Los «Apuntes estadísticos» del Dr. Andrés Lamas. Montevideo, Imprenta de El Siglo Ilustrado. Apartado de la Revista del Instituto Histórico y Geográfico del Uruguay, Montevideo, Tomo VI, n. 1, p. 25-195,1928.[1842].

ISIDORE DUCASSE comte di Lautréamont. Opere complete. Milano, Feltrinelli. (Nota introduttiva di Giorgio Celli e di Antonio Porta). 1978. [Edición bilingüe francés-italiano].

ICONOGRAFÍA de Montevideo. Montevideo, Concejo Departamental de Montevideo. Prólogo de Ariosto D. González, p. 7-84. 1955. [Ilustraciones diversas y fichas].

LAMAS, A. Notice sur la République Oriental de l'Uruguay: documents de statisque concernant sa population indigéne et exotique et le développement de sa richesse. Acompagnés de quelques relatives aux questions politiques et internationales qui s'agitent au Rio de la Plata. Paris: Guillaumin. 1851.

MAILLEFFER, M. Informes diplomáticos de los Representantes de Francia en el Uruguay. Revista Histórica, Montevideo, 2a época, Tomo XXVI, n. 76-78, p. 255-389. 14/III/1868. Traducción de Margarita Carámbula de Barreiro.

- Informes comerciales del Representante de Francia en el Uruguay M. Martin Maillefer (1853-1854). Revista Histórica, Montevideo, 2a época, Tomo XXXII, n. 94-96, p. 529-580, agosto de 1962. (Advertencia de La Dirección [Juan E. Pivel Devoto]. Traducción de Margarita Carámbula de Barreiro).

MUÑOZ, D. Cristina. Bosquejo de un romance de amor. Montevideo: Tipografía y Estereotipia La Moderna,1885.

\section{Historia, crítica, teoría}

ARDAO, A. Racionalismo y liberalismo en el Uruguay. Montevideo: Departamento de Publicaciones de la Universidad de la República.1962.

- Espiritualismo y positivismo en el Uruguay. Montevideo: Departamento de Publicaciones de la Universidad de la República.1968.

. Etapas de la inteligencia uruguaya. Montevideo: Departamento de Publicaciones de la Universidad de la República. 1971. 
ARDAO, M.J. El Palacio Taranco. Almanaque del Banco de Seguros del Estado. Montevideo, p. 61-70, 1973-1974.

BARRÁN, J. P.; NAHUM, B. Historia política e historia económica. Montevideo: Ediciones de la Banda Oriental. 2002.

BENJAMIN, W. Franz Kafka. En el décimo aniversario de su muerte. Sobre Kafka. Textos, discusiones, apuntes. Buenos Aires: Eterna Cadencia, 2014 [1934]. (Editado por Hermann Schweppenhäuser. Traducción, prólogo y notas de Mariana Dimópulos).

CASTELlanOS, A. R. Historia del desarrollo edilicio y urbanistico de Montevideo (1829-1914). Montevideo: Junta Departamental de Montevideo, Biblioteca José Artigas. 1971.

- Timoteo Aparicio, el ocaso de las lanzas. Montevideo: Ediciones de la Banda Oriental. 1977. (Colección "Los Hombres", 8).

- La historia del Teatro Solis. Montevideo: Intendencia Municipal de Montevideo. 1989.

DUPREY, J. Voyageaux origines françaises de l'Uruguay. Montevideo: Instituto Histórico y Geográfico del Uruguay. 1952.

FERNÁNDEZ SALDAÑA, J. M. [3/XII/1939]. Cincuentenario del Barrio Reus. In: FERNÁNDEZ SALDAÑA, J. M. Historias del viejo Montevideo, t. II. Montevideo: Arca, p. 92-97. 1967.

- Viejos hoteles de Montevideo. Suplemento Dominical de El Día, Montevideo, n. 604, 13/VIII/1944.

GUILLOT MUÑOZ, Á. Lautréamont à Montevideo. Temoignages inédits rassemblés par Álvaro Guillot-Muñoz. Paris:La Quinzaine Littéraire. 1972.

GUILLOT MUÑOZ, G.; GUILLOT MUÑOZ, Á. (1925) [1974]. Lautréamont \& Laforgue. Montevideo, Casa de la Amérique Latine. (Trad. al español de María Elena Martínez de Guillot. Montevideo, Arca. 1974).

GUILLOT MUÑOZ, G.; GUILLOT MUÑOZ, Á. [31/III y 9/VI/1935]. La leyenda de Lautréamont. In: GUILLOT MUNOOZ, G. Escritos. Montevideo: Biblioteca Artigas, Colección de Clásicos Uruguayos, p. 5-30. 2009. (Edición, prólogo y notas de Pablo Rocca).

LEFRÈRE, J-J. Isidore Ducasse. Auteur des Chants de Maldoror, para le comte de Lautréamont. Poitiers: Librairie Arthème Fayard. 1998.

ODDONE, J. A. La formación del Uruguay moderno. La inmigración y el desarrollo económico-social. Buenos Aires: Eudeba. 1966. 
PICHON-RIVIÈRE, E. Notas para la biografía de Isidore Ducasse, conde de Lautréamont, 1846-1870. La Nación, Buenos Aires, 14 de abril, 1946, p. 2.

PIVEL DEVOTO, J.E.; RANIERI DE PIVEL DEVOTO, A. Historia de la República Oriental del Uruguay. Montevideo: Ed. Medina, $3^{\mathrm{a}} \mathrm{ed}$. 1966 [1956].

REAL DE AZÚA, C. El centenario de Berro y Flores: el día de los cuchillos largos. In: . Historia y politica en el Uruguay. Montevideo: Cal y Canto, p. 143-154, 1997 [23/II/1968]. (Prólogo de G. Caetano y J. Rilla).

ROCCA, P. La guerra de los textos, los textos en la guerra. Letras, Universidade Federal de Paraná, Curitiba, n. 94, junio-dezembro, 2016, p. 106-126. Disponible en: http://revistas.ufpr.br/letras/issue/ view/2270.

RODRÍGUEZ MONEGAL, E.; PERRONE-MOISÉS, L. Lautréamont austral. Montevideo: Ediciones de Brecha, 1995.

Pablo Rocca. Doctor en Letras por la Universidade de Sáo Paulo. Profesor Titular de Literatura Uruguaya en la Facultad de Humanidades y Ciencias de la Educación (Udelar, Montevideo). Fundó en 1999 y dirigió hasta 2016 el archivo literario de tal institución universitaria. Investigador, Nivel II, de la ANII (MEC, Uruguay). Traductor del portugués, entre otros, de Machado de Assis, Murilo Rubiáo, Lima Barreto, Sergio Faraco. Entre sus libros: 35 años en Marcha (Crítica y literatura en el semanario Marcha y en Uruguay), 1991 [reed. corregida y ampliada en 2015]; Horacio Quiroga, el escritor y el mito, 1996 [reed. 2007]; Angel Rama, Emir Rodríguez Monegal y el Brasil: Dos caras de un proyecto latinoamericano, 2006; Editó en 2016 la correspondencia entre Antonio Candido y Ángel Rama, publicada en portugués en 2018. E-mail: pabloroccapesce@gmail.com

Recebido em: 08/07/2018

Aceito em: 20/12/2018 


\begin{abstract}
ANEXO I
Papeles de sus bienes, asuntos comerciales y particulares de François Ducasse (Folios 7 al 11) ${ }^{11}$

[folio 7 A] En Montevideo á veintiocho de Noviembre de mil ochocientos ochenta y nueve, á efecto de practicar el inventario ordenado de los bienes quedados al fallecimiento de D. Francisco Ducasse, el Oficial de Justicia, asistido del infrascrito Escribano y del Depositario Judicial, se constituyó en el Hotel de las Piramides, y en la pieza que habitó el finado Ducasse, y previo reconocimiento de los sellos puestos en la puerta de dicha habitacion, los que se encontraron en perfecto estado, se procedió al citado inventario en la forma siguiente:
\end{abstract}

Seis acciones del Banco Comercial, de cuatrocientos pesos cada una, número mil ciento novela y nueve al mil ochocientos cuatro. Seis acciones del Banco Nacional, de mil pesos cada una, número mil seiscientos, mil [folio $7 \mathrm{~B}$ ] setecientos veinticinco, mil doscientos noventa y tres, doscientos ochenta y ocho, setecientos cincuenta y dos, trescientos noventa y seis.

Cinco acciones del Banco Nacional, de cien pesos cada una, número mil quinientos noventa y uno, mil quinientos noventa y dos, mil seiscientos seis, mil seiscientos setenta y cuatro, mil seiscientos setenta y cinco.

Catorce títulos de Deuda Unificada, de quinientas libras cada una, número ocho mil nueve-cientos cincuenta y uno al cincuenta y cuatro, ocho milnovecientos cincuenta y seis al ocho mil nuevecientos sesenta y cinco.

Diecinueve títulos de Deuda Unificada, de cien libras cada uno, número cuarenta y ocho mil ochocientos ocho, sesenta y cuatro mil ochenta y seis a setenta y sesenta y cuatro mil ciento tres.

[folio 8 A] Una libreta cuenta corriente con el Banco Comercial, hasta el veinte de julio último, resultado un saldo de diez mil cien pesos, ochenta centésimos.

Una libreta de cheques contra el mismo Banco, del uno al quince por giros.

Un memorandum, sobre título y deuda Francesa.

Un Diploma de Bachiller.

Un testamento ológrafo en sobre habierto [sic], otorgado por el finado Ducasse, en mil ochocientos ochenta y uno.

Dos vales de la Deuda Consolidada, de doscientos pesos cada uno, Dos vales de la misma Deuda, de quinientos pesos cada uno.

Uno id. de mil pesos.

Uno id. de cien id.

Uno id. de cuarenta id.

11 La transcripción se ajusta estrictamente al original, es decir que no se moderniza la ortografía. Sólo se hace notar errores que podrían, en principio, pasar por confusiones de esta versión. En algunos casos en notas al pie se hallarán aclaraciones que se entienden imprescindibles para una mejor comprensión del documento. 
Un recibo de venta de doscientas acciones integradas del Banco Nacional, con la consiguiente numeracion: cuatrocientos sesenta [folio 8 B] y cuatro, quinientos noventa y cinco, seiscientos noventa y ocho y seiscientos noventa y nueve; cuyos títulos son de cincuenta acciones cada una, vendido á D. Pablo Calatayud en 31 de enero de 1888 .

Un recibo por los intereses de las acciones arriba expresadas.

Un vale por la cantidad de mil quinientos pesos, que vence el cinco de setiembre del año proximo venidero, firmado por Doña Luisa A. Duviasio.

Un vale por cien pesos, deudor D. Juan B. Fontan.

Otro id. por cien pesos, deudora Dońa Julia M. de Roquero.

Otro id. por mil pesos, deudor D. Juan Horre.

Otros id, por doscientos cuatro pesos, deudor D. José Suarez.

Otros id. por seiscientos noventa y dos pesos, deudor D. H [¿̨?] Denix.

Un vale por dos mil quinientos pesos, deudora Dońa Luisa [folio 9 A] M. de Bonato.

Otro id. por trescientos pesos, deudor D. M. Montagne.

Otro id. por doscientos pesos, deudor D. P. Mounix.

Otro id. por doscientos pesos, deudor D. P. Duro.

Un recibo del Banco Ingles del Rio de la Plata, por depósitos en prenda, de veintitrés mil quinientos pesos oro, en títulos de Deuda Unificada.

Una libreta de apuntes.

Un legajo de papeles, cartas, recibos etc.

Un crédito hipotecario por diez mil pesos, otorgados por D. Gabino Perdomo á favor del Sr. Ducasse, en escritura de fecha 19 de Octubre del corriente año por ante el Escribano D. Juan F. Moratorio.

Un crédito hipotecario por cuarenta mil pesos, otorgado por D. José Etcheverry en fa[folio $9 \mathrm{~B}$ ] vor del Sr. Ducasse, con fecha once de julio del año próximo pasado por ante el mismo escribano Moratorio.

Otro crédito hipotecario por catorce mil pesos, otorgado por D. José Fargas, con fecha cuatro de Febrero del corriente año.

Otro crédito hipotecario por veinte mil pesos, otorgado por D. Manuel Otero, con fecha trece de Octubre del ańo último por ante el Escribano D. Juan F. Moratorio.

Otro crédito hipotecario por diez mil pesos, otorgado por D. Isidro Fynn, con fecha trece de Marzo de mil ochocientos ochenta y cinco, ante el mismo Escribano Moratorio.

Otro crédito hipotecario, por ocho mil pesos, deudor D. José Montero [ilegible], con fecha primero de Julio del ochenta y siete, ante [el] mismo Escri[folio 10 A]bano Moratorio.

Otro crédito hipotecario por diez mil pesos, deudora Dońa Luisa A. Dubian, con fecha cinco de Setiembre del ochenta y cinco, ante el mismo Escribano Moratorio. 
Otro crédito hipotecario por dieciocho mil pesos, deudor D. Luis Melian Lafinur, fecha catorce de Mayo último, ante el mismo Escribano Moratorio.

\section{Inmuebles}

Un terreno con lo en el construido, situado en la manzana número ciento sesenta y cinco de la Nueva Ciudad compuesto de siete metros, sesenta y cinco centimetros de frente al Sud sobre la calle de Soriano; cuyos terrenos adquirió por compra á D. Carlos Suneguirico [¿̨?], con fecha primero de junio de mil ochocientos ochenta y cinco, escritura que autorizó en esta Ciudad el [folio 10 B] Escribano D. Juan F. Moratorio.

Un terreno con lo en el construido, situado en la calle de Cámaras de esta Ciudad.

Un inmueble [que] adquirió del Dr. Alfredo Vasquez Acevedo, en escritura de fecha veintinueve de Setiembre de mil ochocientos ochenta y uno, que autorizó en esta Ciudad el Escribano D. Juan F. Moratorio. mil pesos.

Una poliza de Seguros, sobre varias propiedades del Sr. Ducasse, por seis

Dinero

Trescientos ochenta y un pesos, once centésimos.

\section{ANEXO II}

Los últimos objetos de François Ducasse

A continuación del inventario precedente se encuentra el capítulo "Ropas y alhajas", en la misma foja 10 B,que separamos de la parte anterior con la finalidad de comparar este arqueo con el que se realizó años después de los mismos objetos en el remate:

Una cigarrera de marfil.

Un abanico, varillas de hueso.

Un reloj de oro, num. 2938.

Una cadena al parecer oro.

Una cigarrera o tabaquera dorada.

Un par de carabanas, con piedra.

//folio $11 \mathrm{~A} / /$

Una cadena de perlo [¿?], con eslabones de oro.

Dos pares de gemelos para teatro.

Un asentador para navaja.

Una relojera.

Un pañuelo de seda. 
Un revólver.

Dos bastones.

Un paragua [sic].

Un par botines.

Tres volúmenes encuadernados.

Un par de espejuelos.

Una fosforera al parecer plata.

Una tabaquera.

Tres tijeras.

Dos paños crochet.

Un baúl.

Dos frac.

Un saco de franela.

Un id. pantalón y chaleco casimir.

Una levita negra.

Tres id. id.

Cinco pantalones negros.

Seis levitas negras.

Una valija.

//folio $11 \mathrm{~B} / /$

Tres sobretodos.

Cinco chalecos.

Un saco.

Cinco pantalones blancos.

Dos calzoncillos.

Un ¿cristal?

Cinco pares de medias.

Seis chalecos.

Cuatro camisas blancas.

Veinticuatro corbatas.

Una camiseta de lana.

El informe concluye, luego de las formalidades del caso, "no habiendo más bienes para inventariar". Lo firman, a fojas 12 A, Augusto Haurie, Luciano Ducasse, Alguacil M. Lerena [¿̨?], Pedro Yacachoury, Juan B. Ducasse, A. Quilez [¿̨?], Belarmino Moreira y Enrique Torres.

Cerradas todas las actuaciones, el Sr. Enrique P. Torres informa al juez sobre el preciso producto de lo rematado que, como se verá, no fue todo lo que se encontró el 18 de noviembre de 1889: 
Cuenta de venta y líquido producto de los siguientes artículos vendidos en remate público por cuenta y órden del Sr. Juez Juez $\mathrm{L}^{\mathrm{do}}$ en lo Civil de $2^{\circ}$ turno y perteneciente al intestado FcoDucas [sic]

1 Frac

$\$ 1 "$

1 Saco franela

$\$ 1,10$

1 Pantalon 1 Saco y 1 Chaleco casimir

$\$ 3,30$

5Levitas negras

c/u $\$ 1,30$

$\$ 5,20$

1 Saco y 5 pantalones n[egros]

$\$ 4,50$

1 reloj de oro No 2938

$\$ 8$ "

1 cadena al parecer oro

$\$ 2$ "

5levitas $\mathrm{n}$ [egras]

$\$ 2,40$

1 sobretodo

$\$ 6 "$

[Ilegible, dańado en el documento] y 2 calzoncillos

$\$ 1,60$

[Ilegible, dañado en el documento]

2 pantalones y una camiseta larga

$\$ 4 "$

5 pantalones blancos y 5 p[ares] de medias

$\$ 2,10$

1 pañuelo seda y dos paños crochet

$\$ 1 "$

1 paraguas

$\$ 0,70$

2 camisas

$\$ 0,60$

1 baúl

$\$ 1,20$

2 bastones

$\$ 3,60$

1 anteojo $\mathrm{p}^{\mathrm{a}}$ teatro

$\$ 3,80$

[Ilegible]

$\$ 0,25$

2 pares medias

$\$ 0,15$

2 camisas blancas

$\$ 2,50$

1 pańuelo seda $\mathrm{n}$ [egro]

$\$ 0,35$

[Sumar de la nota No 1

$\$ 55,35$

1 Relojera

$\$ 0,30$

[Ilegible] Corbata

$\$ 0,65$

1 Chaleco

$\$ 0,50$

1 Diccionario Universal

$\$ 0,70$

2Libros en Francés

$\$ 0,30$

1 Asentador y 2 Navajas

$\$ 0,60$

1 Anteojo p[ara] teatro

$\$ 1$ " 
2 Tijeras y 2 Sellos

$\$ 0,10$

2 Calzoncillos 1 Camiseta y 2 p [ares] tiradores $\$ 1,30$

1 par botines

$\$ 0,30$

Paños 1 grande y 1 chico

A Deducir

Por Conducion al Depósito

$\$ 0,80$

Por Avisos

Por Honorarios curso definitivo

$\$ 1,20$

Por mi comision de venta

$\$ 2,48$

8,12

Saldo líquido a s/f

$\$ 54,18$

S.E.u/o.

Montevideo, Diciembre 6/1890"

El 26 de mayo de 1891 el mismo "Depositario Judicial de Bienes Muebles de los autos del Intestado Francisco Ducas", presenta una nota en la que hace constar: "Que a los efectos que haya lugar hago presente á Ud. que varias de las alhajas cuya venta debía proceder, me han sido robadas á cuyo efecto he dado cuenta á la policía y cuyo sumario sigue aun instruyendose como podré justificarlo en oportunidad y tramita ante el Juzgado Ldo Correccional [...]”. Comparados los dos inventarios, trabajo que no se tomó el Sr. Torres, o por lo menos al que no hace mención a pesar de que su firma consta al final del primero (folio $13 \mathrm{~A}$ ), resulta que lo sustraído va más allá de las alhajas. Faltan:

Una cigarrera de marfil.

Un abanico de varillas de hueso.

Una cigarrera o tabaquera dorada.

Un par de carabanas, con piedras.

Un revólver.

Una fosforera al parecer de plata.

Una tabaquera.

Una tijera.

Una valija.

En esa valija, tal vez, se introdujo lo anterior para sacarla del depósito establecido por orden judicial. No está claro el faltante de ropa: por ejemplo, de 5 chalecos registrados en el inventario original sólo se habría rematado uno; queda un sobretodo, salvo que se lo notifique de otro modo en esta segunda ocasión. Si hubo o no algún recuerdo de su hijo entre todo esto es difícil conjeturarlo. 


\section{ANEXO III}

La familia Ducasse. Informe de Pedro Aramburú (folio 302)

Intestado Ducasse

Sor. Juez L[etrado] de lo Civil

Pedro Aramburú por Don DroctovéDucasse, D. Francisco Ducasse ${ }^{12}$ y Dońa Lucia o LeceaDucasse de Suarez, enlos autos de lasucesion de Don Francisco Ducasse, a VS. como mejor proceda de derecho digo:-

I. Que como se comprueba por las partidas de nacimiento y defuncion contenidas en el octavo legajo y las expedidas por el Sor. Cura de la Matriz que acompaño, una de bautismo y otra de defuncion, resulta comprobado: - 10 Que Don Francisco Ducasse, ${ }^{13}$-la persona de cuya sucesion se trata, -es hijo legítimo de D. Luis Ducasse Mettre y de Doña Marta Damaré- 2o Que Don Francisco Ducasse fué casado con Doña Celestina Jacquet Davevac [sic], la cual falleció en esta ciudad el 10 de Diciembre de 1847. Partida No $2-^{14} 3^{\text {a }}$ Que del matrimonio entre D. Francisco Ducasse y Da Celestina JacquetDavevacnació en esta ciudad el 4 de Abril de $1847^{15}$ un hijo legítimo llama (folio 302 B) do Isidoro Luciano -partida No 1 . Que ese hijo, Isidoro Luciano Ducasse, falleció en Paris el 24 de Noviembre de 1870- Segunda partida del octavo legajo.

Con estos documentos y con lo que resulta de la informacion de f... [sic], queda plenamente comprobado que Don Francisco Ducasse era, a su fallecimiento, viudo, y no tenía hijos ni descendientes legítimos.

II. Del certificado del Actuario (greffer) del Tribunal Civil de $1^{\text {a }}$ Instancia de Tarbes, Altos Pirineos, quinto legajo -resulta comprobado que no existe ningún registro del Estado Civil de las comunas de Bazet y de Chis, distrito de Tarbes, en el periodo de 1789 a 1802 .

De la información, ó acta de notoriedad - quinto legajo-, consta tambien la notoriedad pública del matrimonio celebrado el año 1798, entre Luis Ducasse, llamado algunas veces Mettre ó Metre y Marta Damaré, los padres de Don Francisco Ducasse de cuya sucesión se trata, y como lo comprueba "un proceso verbal (folio 303 A) de publicación de su casamiento, labrado en la Alcaldia de Bazet el seis de "Pluvioso del año siete de la República".

De esa notoriedad y posesión de estado civil de D. Luis Ducasse Mettre ó Metre y Dońa Marta Damaré, como esposos legítimos, me ocuparé por separado en párrafo especial.

12 Por evidente distracción, el redactor del informe en lugar de poner Luciano escribe Francisco, confundiendo al hermano sobreviviente con el fallecido cuya parte de los bienes reclama.

13 Los textos que consignamos en cursiva están subrayados en el original.

14 Ninguna de las partidas ni el árbol genealógico estaban en el expediente cuando lo consultamos en febrero de 2016.

15 A la lectura inadecuada da la documentación de que disponían sobre el apellido de la esposa de Ducasse, Davevac en lugar de Davezac, se agrega este error que retrasa un ańo el nacimiento de Isidore. 
De las partidas de defunción contenidos en el mismo quinto legajo resulta que Don Luis Ducasse y Doña Marta Damaré, fallecieron, respectivamente el uno el 20 de Julio de 1830 y la otra el 11 de Agosto de 1856- En una y otra partida de defunción, y después de mas de treinta, cincuenta y tantos ańos de la fecha del matrimonio, se expresa que eran legítimos esposos, comprobando eso solo una posesión de estado de mas de medio siglo.

Unida esta comprobación á la del párrafo I resulta probado que al fallecimiento de Don Francisco Ducasse no tenía éste ni descendientes, ni ascendientes legítimos, ni conyuge sobreviviente- Se trata, pues, de una herencia (folio 303 B) transversal ó sea de colaterales.

III- De los documentos contenidos en el 1er y $2^{\circ}$ legajo resulta plenamente comprobado, además de lo ya expuesto con la comprobación de otros documentos: - $1^{\circ}$ La notoria posesión de estado civil, como legitimos esposos de Don Luis Ducasse, llamado algunas veces Mettreó Metre por una finca que tenia ese nombre, lo que es muy frecuente en Francia y en toda Europa, y Da Marta Damaré- Esa posesión notoria que empieza el siglo pasado, y que tiene por antecedente plenamente comprobado la no existencia del Registro civil, en Bazet, del año en que se celebró el matrimonio, continua durante toda la vida de los esposos, mas de medio siglo en uno de ellos y treinta y tantos ańos en el otro, aparece en las actas de nacimiento de los hijos y es comprobada por declaraciones de testigos- $2^{\circ}$ la posesión notoria del estado civil, como hijos legítimos de Don Luis Ducasse y Doña Marta Damaré, por Don Francisco Ducasse y sus hermanos D. Bernardo Luciano Ducasse (folio 304 A), Don Marcos Ducasse, Dońa Juana Ducasse de Joly y Do Juana Ducase [sic] de Guinle, resulta tambien comprobada de las actas de notoriedad contenidas en el mismo legajo-, ó sea de la informacion sumaria levantada al efecto y de la que, con trascripción de las actas del estado civil, resulta formada la genealogia de la familia Ducasse, empezando por los causantes comunes, ó sea los esposos Luis Ducasse y Marta Damaré-, hasta llegar á los miembros actuales de esa familia.

Llamo la atención sobre el árbol genealógico que obra en el segundo legajo, y que confirma lo expuesto en los parágrafos anteriores.

A la simple vista y con solo recordar los comprobantes que he mencionado se ahorrarán Vs. y el Sor. Fiscal la pesada tarea que he debido imponerme para facilitarles el trabajo.

IV. Comprueban plenamente que los hermanos de Don Francisco Ducas (folio 304 B) se eran cuatro: -D. Bernardo Luciano Ducasse,- D. Marcos Ducasse,- Da Juana Ducasse de Joly y Doña Juana Ducasse de Guinle, las actas de nacimiento que encabezan los legajos sexto, séptimo, noveno y décimo y en los que figuran como hijos legítimos del mismo padre y la misma madre D. Luis Ducasse y Doña Marta Damaré.

Las actas de notoriedad establecen tambien el hecho de que no hubo otros hermanos de Don Francisco Ducasse que los ya nombrados.

A falta, pues de descendientes y ascendientes legítimos, no existiendo cónyuge ni hijos naturales ó adoptivos-, información sumaria de f. 22, los herederos legítimos de Don Francisco Ducasse, suponiendo intenstada su sucesion, son sus hermanos legítimos, y en representacion de estos, si faltase alguno, la descendencia legitima de esos hermanos. Arts. 983 y 989 del Código Civil. 
V. Para dejar bien claro y netamente establecido quienes son los hermanos actuales de Don Francisco Ducasse, voy á ocupar (folio 305 A) me de cada rama colateral ó sea de cada uno de los hermanos estableciendo su existencia ó quien representa sus derechos por razon de sucesionócesion de esos derechos hereditarios.

Marcos Ducasse- El legajo sexto comprueba lo siguiente: $1^{\circ}$ Que D. Marcos Ducasse casó legítimamente con Doña Maria Juana Bernisson el año 1835Partida ó acta de matrimonio № 2- 2० Que Don Marcos Ducasse falleció el 17 de Enero de $1872-3^{\circ}$ Que son hijos legítimos del matrimonio de D. Marcos Ducasse con Doña Juana Bernisson: D. Francisco Ducasse, D. Droctové Ducasse y Doña Lecea o Lucia Ducasse de Suarez Fernandez -Actas No5-6 y 7- mis representados en este asunto en virtud del poder que obra a f. 41 .

En representación, pues de su padre D. Marcos Ducasse, hermano de Don Francisco, son herederos de éste sus expresados sobrinos legítimos D. Francisco D. Doctrové y Dońa Lecea ó Lucia Ducasse de Suarez Fernandez-

Juana Ducasse de Joly - De las actas de (folio 305 B) estado civil contenidas en el septimo legajo resulta plenamente comprobado: $-1^{\circ}$ el matrimonio legítimo celebrado entre Doña Juana Ducasse con D. Alexis Joly- Acta No 2- $2^{\circ}$ El fallecimiento de Doña Juana Ducasse de Joly, viuda de éste, falleció el 22 de Setiembre de 1886- Acta No $3-3^{\circ}$ Que del matrimonio de Dońa Juana Ducasse con D. Alexis Joly existen dos hijos legítimos llamados Maria Justina Joly y Domingo Joly-Actas de nacimientos Nos 4 y 5 del mismo legajo-

Los derechos, pues, de Dońa Juana Ducasse de Joly, estarian representados por sus dos hijos legítimos Maria Justina y Domingo Joly, sino hubieran pasado a mis poderdantes D. Francisco Ducasse, D. Droctové Ducasse y Doña Lucia ó Lecea Ducasse de Suarez Fernandez como lo comprueban los documentos que mencionaré mas adelante-

Bernardo Luciano Ducasse. El legajo noveno contiene solo el acta de nacimiento de D. Bernardo Luciano Ducasse, hermano legítimo de D. Francisco, de cuya sucesión se trata, y que seria su heredero legítimo sino (folio 306 A) hubiera pasado sus derechos á mis poderdantes D. Francisco, D. Doctrové y Da Lucia o Lecea Ducasse de Suarez Fernandez a mérito del documento á que haré referencia y acompaño á este escrito. Es por esta circunstancia de existir un hermano y sobrinos legítimos que he hablado del derecho de representación-

Juana Ducasse de Guinle - Los documentos contenidos en el décimo legajo comprueban plenamente: $1^{\circ} \mathrm{El}$ matrimonio legítimo celebrado entre Dońa Juana Ducasse, -otra hija legítima del mismo nombre que la casada con Joly, con Don Antonio Guinle -Acta de Matrimonio No 2- $2^{\circ}$ El fallecimiento de Doña Juana Ducasse de Guinle ocurrido el 2 de Febrero de 1854 - Acta de defunción No 3.- $3^{\circ}$ Que del matrimonio de Dońa Juana Ducasse con D. Antonio Guinle nacieron los siguientes hijos legítimos: -Domingo Guinle, -acta No 4; Marcos Guinle, Acta No 5 y Alexis Guinle, -Acta No 6- $4^{\circ}$ Que Alexis Guinte falleció el 20 de Abril de 1876-

De lo expresado y comprobado resulta: Que (folio 306 B) los derechos de Dońa Juana Ducasse de Guinle, en virtud del derecho de representación, corresponderían á sus hijos Domingo Guinle y Marcos Guinle si no hubieran pasado, como ha sucedido á mis poderenates ya mencionados D. Francisco D. Droctové y a 
Da Lucia o Lecea Ducasse de Suarez Fernandezsegun consta de los documentos que acompaño y á que haré referencia.

Resúmen. Resumiento lo expuesto resulta: -que los herederos legítimos de Don Francisco Ducasse son: Su hermano Don Bernardo Luciano Ducasse: -sus sobrinos Francisco, Droctové y Lucia ó Lecea Ducasse en representación de su finado padre Don Marcos, hermano de Don Francisco; sus sobrinos D. Domingo, Doña Maria Justina Joly, en representación de su finada madre Doña Juana Ducasse de Joly, -D. Marcos y D. Domingo Guinleen representación de su finada madre Doña Juana Ducasse de Guinle.

Pero como los derechos de los sucesores de Dońa Juana Ducasse de Guinle, de Doña (folio 307 A) Juana Ducasse de Joly y los de D. Bernardo Luciano Ducasse han pasado á mis poderdantes, segun lo comprueban los documentos adjuntos de que me ocuparé en seguida, resulta que los herederos universals de D. Francisco Ducasse, por sí y como cesionarios de su tío y primos hermanos mencionados, lo son Don Francisco, D. Droctové y Doña Lucia o Lecea Ducasse de Suarez Fernandez.

VI. De los documentos públicos que acompaño con los títulos de "Consentimiento de ejecucion del testamento Ducasse", "Entrega de Legados Ducasse", y "Cesion" resulta plenamente comprobado lo siguiente: - 1. Que Dońa Maria Justina Joly y D. Domingo Joly, como únicos hijos y representantes de Dońa Juana Ducasse de Joly, D. Domingo Guinle y Don Marcos Guinle, como únicos representantes despues del fallecimiento de su hermano Alexis Joly, por escritura pública otorgada ante el Notario de Tarbes Alejandro Carrere y su colega, expresaron su consentimiento á la ejecución del testamento ológrafo de D. Francisco Ducasse (folio 307 B) del cual a f. 31, copia testimoniada y copia tambien en la misma escritura que acompańo, agregando ademas que "apreciaban el dicho testamento en su conjunto y contenido, se prohiben mutua y expresamente el discutirlo por cualquier motivo que sea y consienten en que reciba su plena y entera ejecución en todas sus disposiciones sin excepción ni reserva, queriendo que sea ejecutado segun la forma y el tenor, como si hubiese sido hecho según las leyes no sólo del pais donde falleció el testador, sino también de todos los otros paises donde se hallasen bienes pertenecientes á su sucesión, etc, etc. Pag. $7^{\mathrm{a}}$ y pag 8 del legajo.

Ese contrato no tiene mas reserva que la consignada en la pagina $8^{\mathrm{a}} \mathrm{de}$ la traducción que dice así: "El presente consentimiento para la ejecución se da bajo la reserva expresa del pago del legado de quince mil francos hecho por el finado á cada uno de los sobrinos y sobrina [sic] etc, etc."

Ademas de eso, y de esa misma escritura resulta, que los Guinle y Joly dieron (folio 308 A) á mi poderdante Don Droctové Ducasse plenos y absolutos poderes para la liquidación de la sucesión de Don Francisco Ducasse, judicial ó estrajudicialmente, con facultad de vender los bienes muebles e inmuebles, etc. etc.

Pero ese poder es inútil porque los sobrinos de Don Francisco Ducasse, -Domingo y Maria Justina Joly, Marcos y Domingo Guinle,- consecuentes con su compromiso de respetar en un todo la voluntad de aquel expresada en el testamento ológrafo, en la misma escritura acompañada, de recibo y chancelacion de los legados que en aquel testamento les hizo su tío, cedieron á favor de mis poderdantes todos sus derechos en la suecesión de Don Francisco Ducasse. 
En seguida de otorgar recibo de esos legados declaran que: "Hacen cesion y transferencia si necesario fuera, al dicho Sor. Droctové Ducasse de todos los otros mas fuertes derechos que pudieran tener que pretender sobre la sucesion de dicho finado Sor Francisco Ducasse (folio 308 B), en virtud de cualquier título y por cualquier motivo (causse) que fuera". Textual. Página 6 del legajo titulado "Entrega de Lagados", etc.

Aunque esa cesion aparezca hecha solo á Don Droctové Ducasse, es para él y sus hermanos D. Francisco Ducasse y Doña Lucia ó Lecea Ducasse de Suarez Fernandez, de quienes era apoderado en ese acto y consecuentes con el propósito de hacer cumplir la voluntad del finado D. Francisco Ducasse. He recibido al respecto instrucciones expresas de Don Droctové Ducasse. Esa escritura de conformidad con la ley, ha sido inscripta ó anotada en el Registro General de Ventas.

$2^{\circ} \mathrm{La}$ misma cesion de derechos sucesorios que hicieron á favor de mis poderdantes sus primos hermanos los Guinle y los Joly la ha hecho tambien su tio D. Bernardo Luciano Ducasse, segun consta de la escritura pública de cesión que acompaño.

Don Luciano Ducasse, como los Guinle (folio 309 A) y Joly han querido respetar la voluntad del finado D. Francisco Ducasse, cualquiera que sea el valor legal de su testamento ológrafo y solo se ha reservado el derecho á la venta Francesa, existente en Francia, y que le acordaba ese mismo testamento- Esa escritura de cesion de derechos hereditarios ha sido anotada en el Registro General de Ventas como lo prescribe la ley.

Todas las partidas, informaciones, actas de estado civil, escrituras públicas, etc. etc. estan debidamente legalizadas por los respectivos Consulados de la República.

VII. Resumen total. De todo lo expuesto y comprobado resulta: -que mis poderdantes Don Francisco y Don Droctové Ducasse y Doña Lucia o Lecea Ducasse de Suarez Fernandez, por sí mismos y como cesionarios de D. Luciano Bernardo Ducasse, Doña Maria Justina Joly, Don Domingo Joly, D. Marcos Guinle y Don Domingo Guinle, con los herederos universales de su finado (folio 309 B) tio Don Francisco Ducasse con arreglo al art. 989 del C. Civil, pues el testamento ológrafo de dicho Sor. Ducasse no tiene valor legal en la República con arreglo á las disposiciones del C. Civil en el Capítulo del testamento.

En consecuencia y prévia audiencia del Sor. Fiscal de lo Civil

Sírvase Vs declararlo así: Será justifica. Monto Octubre 9 de 1890

Pedro Aramburú [Firma]

[Timbre de \$0, 50]

Recibido con los recaudos acompańados el nueve de Octubre de mil ochocientos noventa.

Fein [Firma] 